\title{
THE POLITICS OF EDUCATION REFORMS IN KENYA: CRITICAL ASSESSMENT OF THE EDUCATION SYSTEM FROM 1963-2020
}

\author{
David Kamar IMANA ${ }^{1}$
}

\begin{abstract}
The study conducted a critical appraisal of the education system and reforms in Kenya as influenced by the regime of the day. There are various factors that influence educational development in any particular country, namely political, historical, geographical, technological, religious, and ideological factors. The political factor is seen as the steering wheel of education in Kenya during pre-colonial, colonial and post-colonial periods. There is no doubt that educational policies on system reforms are significantly dependent on political and social conditions, which are no longer consistent with the current predominant economic reality. This has made it difficult to come up with better, reliable, and sustainable policies. The historical design was adopted in reviewing educational development under the leadership of the four presidents of Kenya. So far, the first and the second presidents remain known as the ones who have brought the most educational changes in the country. The new 2-6-6-3 education system emphasizes continuous assessment tests rather than the end of cycle tests and is more competencies-based than exam-based (as is the 8.4 system). The policy designers in the education sector should comprehend and embrace education policies since they are expected to give effective leadership and management practices in the development of education. Good education development can only be realized when a country tries to separate educational policies from national politics, clear stipulation of educational policies and their role in national development and a sound implementation of educational reforms. This article digs deeper into education policies and implementation in Kenya in an attempt to provide recommendations and suggestions to improve the educational sector.
\end{abstract}

Keywords: educational system; educational reforms; Kenyan Government

\section{Introduction}

There is definite confirmation that education improves societal well-being; this explains the reason why societies invest profoundly in comprehensive and quality education.

1 School of Business and Economics, Turkana University College, P.O.BOX 111, 30500 Lodwar, Kenya, e-mail: imanadavid@gmail.com 
Households and citizens support public education systems by funding their children's education and by paying taxes (Ngware, 2019). Equal access to quality education is vital for addressing socioeconomic problems of poverty, unemployment and inequality (Reynolds et al., 2014; UNESCO(d), 2017), and the Sustainable Development Goals (SDGs) appropriately capture this idea. The greatest and working tool a nation can offer its youth is education, and a healthy society is nurtured through the provision of quality education that is accessible and relevant (Njagi, 2018; Digolo, 2006). Immediately after gaining independence in 1963, the Kenyan government vowed to eliminate or reduce the three "enemies" of development: poverty, illiteracy, and disease (Imana, 2017). In developing countries such as Kenya, education provision and training of citizens are crucial for economic and social development. For example, Kenya's vision 2030 blueprint, sessional paper No.1 of 2005, and the new constitution of 2010, clearly explained the education policy framework and the county's developmental plans. In order to vividly explain the trend of the education policies and reforms in Kenya, this study divided the explanation into four presidential eras.

Kenya's budgetary allocation to education in the current financial year stands at 494.8 billion shillings which is about US $\$ 4.95$ billion. This means that the education sector receives twice combined allocations for defense, health and the presidency (Ngware, 2019). Generally, there are over 17 million children and youth in education and under training in Kenya. There are over 13 million children and youth currently in primary and secondary schools. In 2018 alone, enrolment in public universities accounted for about 513,000 students, while the rest were in early childhood education and nonuniversities tertiary institutions. The education budget is split as follows: $50 \%$ to the Teachers' Service Commission, $20.9 \%$ to public universities, $21.7 \%$ non-salary allocation to basic education programmes and 3.6\% to technical and vocational training (Ngware, 2019).

The education sector transformation and restructuring can be traced back from the precolonial to the post-colonial era. The educational system during pre-colonial era was based on the western form of education. Christian missionaries launched the western form of education in Kenya around the 18th century and their main aim was only to serve religious purposes and to support western ideologies (Imana, 2017; Sheffield, 1973). The educational aims were further widened to contain basic practical skills in order to meet the colonial government demands at the time. The colonial administration brought in a racially-based education system whereby Africans were taught separately from whites and other races mostly to study "industrial education", whose aim was to prepare them for their colonial masters. Education and training for all empower citizens of a particular country to improve their living standards through participating greatly in economic productivity and growth, alleviating poverty, and utilizing the available socioeconomic opportunities (Romer, 1990; Rosen, 1999; UNESCO(e), 2006; Bwonda, 2013). Owing to the prominence given to education internationally, the United Nations (UN) declared education as a basic human right in 1948. African countries met in Addis Ababa in 1961 and agreed at attaining Universal Primary Education (UPE) by 1980 and at the same time planned to expand all other levels of education. The management of education was re-emphasized in 1990 when 1500 participants from 155 countries including Kenya gathered in Jomtien in Thailand 
and re-affirmed education as a human right by adopting the World Declaration on Education for All (Republic of Kenya, 2005). Therefore, provision of high quality education remains the top most agenda for the African countries as they strive to achieve development and join the league of developed nations in the world. However, quality issues still block the education systems in developing nations (Njagi, 2018; Imana, 2017; Digolo, 2006).

Access to education has generally improved in sub-Saharan Africa with both boys and girls reporting better completion rates in the last two decades (Lewin, 2009; UNESCO (c) UIS, 2018). According to UNESCO(d) (2017), the inequity gap has greatly improved, particularly for girls, although full parity has not been attained generally and learning gaps continue to be high. There is no doubt that Kenya is striving hard to provide quality and affordable education for all. Kenya is amongst the best education providers on the African continent although this being undermined by bad policies, limited educational financing, ethnicity politics, and poor income distribution policy that makes it difficult for Kenya to improve even further as expected. Kenya has had several education commissions that influenced government education policies (Wa Mberia, 2016). Policies guiding the education sector evolved since independence with over six commissions and committees established to review or develop education policies that led to developing self-expression, discipline and self-reliance in an allround educational experience for learners (Mutuku et al, 2019). Some of the key commissions that have been undertaken to review education during this period include the Phelps-Stokes Commission (1924), the Beecher report (1949), the Binns Commission (1952), the Ominde report (1964), the Bessey report (1972), the Gachathi report (1976), the Mackay report (1981), the Kamunge report (1988), the Koech report (1999) and the Odhiambo report (2012). When a country invests more in education development, a number of benefits will be witnessed: an increase in economic growth, an increase in wealth and income distribution, more skilled and trained manpower, more quality opportunities, a drop in population growth, and high life expectancy and good health. Additionally, low crime rates, national peace, and political stability were witnessed (Abuya, \& Musyoka, 2013; Ojiambo, 2009; Amutabi, 2003; Psacharopoulos, 1988).

\section{Problem Statement}

The development of education in colonial Kenya was politically directed and the same trends were realized in post independent period. There is no doubt that educational policy and system reforms are significantly dependent on political and social conditions, which are no longer consistent with the current prevalent economic reality, which makes it difficult to come up with better, reliable, and sustainable policies (Imana, 2017). The ruling and various political parties have been using free basic education policies to win votes from the electorates in Kenya. Political interference by heads of states, delay in reviewing education curriculum and policies, poor policy formulation and implementation are some of the problems that undermine the growth of education in Kenya. The new education system of 2-6-6-3 has been introduced in Kenya to nurture not only academic professionalism, but is also meant to give skills and power to create ideas that propel the economy. This is because the 8-4-4 system deviated from its 
original envisioned purpose and progressively resorted to preparing learners towards passing examinations, acquiring white collar employment and general wealth creation. This article therefore, probes the new education system of 2-6-6-3, compares education system in Kenya, UK and USA, and lastly, explores historical trends of education policies and reforms under the four presidents of Kenya from 1963 to 2020.

\section{Objective}

The main objective this article is to explore historical trends of education policies and reforms during pre-colonial, colonial and post-colonial period in Kenya. The following specific objectives have been identified:

1. To critically assess the educational reforms and development in the republic of Kenya;

2. To examine the new education system of 2-6-6-3 in Kenya;

3. To find out education policies contributions by the four presidents of Kenya (19632020);

4. To compare the education systems in Kenya, UK and USA up to secondary level.

\section{Education System in Kenya}

The government of Kenya has increased universal access to basic education in an attempt to support National Educational Goals, International Conventions on education, and UNESCO instruments by supporting fully free primary and Free Day Secondary Education (Ndonga, 2017). The education system in Kenya has undergone various reforms and restructuring. It first began with the 7-4-2-3 system, then moved to the 8-4-4 system, and to the new 2-6-6-3 education system.

\section{Education System of 7-4-2-3 (1967-1984)}

The 7-4-2-3 systems meant seven years of primary education, four years of secondary education, two years of high school, and three-five years of university education. Under the 7-4-2-3 system of education, children were to do three kinds of examinations before joining the university. Firstly, the East African Certificate of Primary Education (EACPE) for primary education that was done at the end of every seven years. Secondly, the East African Certificate of Education Examination (EACE) for secondary education done at the end of four years. Thirdly, the East African Advanced Certificate of Education (EAAC) for high school education was done after two years.

\section{Education System of 8-4-4 (1985-2021)}

The second president of the Republic of Kenya, His Excellence the late President Daniel Torotich Arap Moi, introduced the 8-4-4 system of education in 1985. The 8-44 system was tailored to improve the problems related to academic education, for example, a scarcity of technical skills. The government of Kenya initially introduced vocational subjects at both primary and secondary education levels under "the 
umbrella" of the 8-4-4-system syllabus (Mwiria, 2002, Republic of Kenya, 2003). The 84-4-system consists of eight years of primary, four years of secondary, and four years of university education. At the end of 8 years of study at the primary level, pupils take a national examination (Kenya Certificate of Primary Education - KCPE). If a pupil passes the KCPE he/she will join a secondary school, which takes 4 years before the student will sit for the secondary school national examinations (Kenya Certificate of Secondary Education - KCSE) in order to study at a higher education level.

Primary Level: This is the first stage of entry to the 8-4-4 education system and students normally take 8 years to complete it. The eight years are divided into three levels: lower primary (grade 1-3), middle primary (grade 4-5), and upper primary (grade 6-8). Grades one to eight are commonly referred to in Kenya as standard 1-8 or class 1-8. Primary education caters to children aged between six and thirteen years or above. The basic education provided at the primary level is meant to prepare students to contribute the talents, skills, and knowledge that they have acquired to the country's development in the future. Although primary education is free for all, it is not compulsory, which makes it difficult for all parents to have their children study. Primary pupils sit for their final examination after eight years of study; the pupils take the Kenya Certificate Education Examination (KCPE), which is controlled by the Kenya National Examination Council (KNEC) under the Ministry of Education, Science, and Technology. Upon receiving the examination results, normally at the end of December of every year, students are able to know if they will be able to join national, provincial, or district secondary schools.

Secondary Level: This is the second phase of the education system in Kenya whereby students take four years before sitting for their final national examinations, commonly referred to as Kenya Certificate of Secondary Education (KCSE). When students pass the KCSE examinations, it enables them to go to university after attaining the required pass points. Public secondary schools in Kenya are categorized into national, provincial, and districts schools. In order for a student to get admitted to above-mentioned categories of secondary schools, he/she needs to have passed the primary school leaving examination (KCPE) where the selection is made according to the students' scores and grades. This means that students that score the highest scores/points get admitted to national schools while those that get scores slightly above average or average get admitted to provisional and districts secondary schools respectively.

University Education Level: This is one of the higher education sector levels in Kenya that includes universities, higher professional education institutes, polytechnics, and industrial training institutes. In this study, the university education level was used as a representation of the higher education level and the study concentrated more specifically on public universities. In order to propel Kenya's economy, there is a need to educate more people at higher levels of learning, such as universities. According to Wanjala and Malechwanzi (2016), there are many individual and social benefits when one obtains a higher education, which has been directly linked to social and economic development as witnessed in rising economic giants such as China. Regarding Kenya's university programs, undergraduate study takes 4 to 6 years, postgraduate (master) study takes 1 to 2 years, and the PhD programs take 3 years. 
In Kenya, the bachelor's programs frequently end with a research project without which one would not be allowed to graduate. Apart from engineering, architecture, veterinary science, and medicine programs, which take 5 to 6 years, the rest of the disciplines take 4 years. At the masters level, one studies between 1 and 2 years and in most cases, the first year is for lectures and the second year is for doing thesis/research work. The highest level in the education hierarchy is the doctoral program, which takes 3 years to complete. Upon successful completion of this program, the titles of $\mathrm{PhD}$ or Dr. phil. are awarded to graduates. In addition to the bachelors, master's and doctoral program provided at the universities, the national polytechnics offer higher professional education and confer diplomas and certificates. Upon completion of a diploma course at the national polytechnics, one can then move on to enroll in a university bachelor's program.

\section{Reasons against the 8-4-4 Education System in Kenya}

The following were the reasons provided for scrapping the current education system (8-4-4):

- it keeps pupils in primary school for too long;

- pupils were taught more subjects which required more textbooks and funding;

- learning amenities were overstretched with the implementation of the 8-4-4 system;

- pupils and teachers needed more time to complete the syllabus, which forced them to have extra learning hours during the schools' closure.

Despite the task forces' recommendations led by former Moi University Vice Chancellor Douglas Odhiambo on the benefits of the new form of educations system, parents and major stakeholders criticized it by saying that it was costlier than the current system. In reply to their claims, the task force explained that the new system of education would be costly of course, but it will be an essential investment that a country makes for its people and that the cost should not be a factor in dismissing the proposed system.

The new education system was tailored to accommodate other disciplines, for example, technical work, self-employment, and wealth creation in the country. The Kenyan pupils would benefit more if only the new system of education would be well organized and implemented. The appraisal for the new education system would be through continuous assessment tests, offered by the respective schools, to enable the learners' transition by evaluating the students' skills, capabilities, and abilities. This is the major reason for scrapping the national examinations for the primary and secondary levels.

\section{Nere Education System of 2-6-6-3}

The structure of the new education system in Kenya is as follows: 2 years of preprimary, 3 years of lower primary, 3 years of upper primary, 3 years of junior/lower secondary, 3 years of senior secondary and 3 years of tertiary education (Wanjohi, 2017). The new education system replaced the 8-4-4 education system, marking the end 
of both the Kenya Certificate of Primary Education and the Kenya Certificate of Secondary Education examinations. According to the task force led by former Moi University Vice-Chancellor Douglas Odhiambo, they recommended that primary and secondary examinations be terminated by 2018 and 2021 respectively. The fourth President of Kenya, H.E. Uhuru Kenyatta approved the proposals for the new system of education.

The new education system of Kenya of 2-6-6-3 puts less emphasis on examinations just like USA does and students remain generalists all the way through to the end of secondary school. The 2-6-6-3 education system emphasizes on continuous assessment tests rather than the end of cycle tests and is more competencies-based than exambased as in 8-4-4 education system. It was estimated that 2-6-6-3 could cost Kshs 340 billion annually to implement it and Kshs 2 billion out of this cost will be used to hire new teachers (Kwach, 2019). In Kenya, it is estimated that 90,000 teachers should be employed to meet the recommended Pupil-Teacher ratio of 40:1.

Pre-primary level of education covers 2 years, namely pre-primary 1 and pre-primary 2 for children aged between 4 and 5 years. Digital literacy and pertinent and contemporary issues will be integrated across all subjects. Lower primary education takes 3 years, covering grade 1,2, and 3 . The age bracket is expected to be between 6 and 8 years. There will be both formative and nationals assessment. Upper primary education covers grade 4 to 6 , starting from age 9 to age 11 years. There shall be formative and national assessment to assess learning outcome. Primary education emphasises on practical oriented learning areas such as Home science, Art and Craft, Music, Drama, Agriculture, and Foreign languages such as French, German, Chinese and Spanish. Secondary education advocated for practical subjects such as Home science, Art and craft, Agriculture and woodwork. Other subjects are more of practical and learners at this stage start specializing in their preferred profession (Wanjohi, 2017).

Junior secondary education covers grade 7, 8, and 9 for those aged between 12 and 14 years. Upper secondary education covers grade 10 to 12 for the age bracket between 15 and 17 years. In this level, there are three learning pathways, namely arts and sports science, social sciences and STEM (science, technology, engineering and mathematics) (Wanjohi, 2017).

Table 1: Comparison between 8-4-4 and 2-6-6-2 Curriculum

\begin{tabular}{|l|l|l|}
\hline \multicolumn{1}{|c|}{ Topics } & \multicolumn{1}{|c|}{ 8-4-4 Curriculum (Old) } & \multicolumn{1}{c|}{ 2-6-6-3 Curriculum (New) } \\
\hline Rationale & $\begin{array}{l}\text { It is about skills preparations for the } \\
\text { World of work. The basic academic } \\
\text { education thought to lack the } \\
\text { necessary content to promote } \\
\text { widespread sustainable (self) } \\
\text { employment }\end{array}$ & $\begin{array}{l}\text { It is about education sector reforms } \\
\text { aligned to 2010 Constitution of Kenya, } \\
\text { Vision 2030 and the Global Standards }\end{array}$ \\
\hline Goal & $\begin{array}{l}\text { Intended for knowledge acquisition } \\
\text { (cognitive development) }\end{array}$ & $\begin{array}{l}\text { It is grounded in competencies (proper } \\
\text { application of knowledge) to real life state } \\
\text { of affairs. }\end{array}$ \\
\hline Focus & $\begin{array}{l}\text { Emphasized competition for } \\
\text { examination grades }\end{array}$ & $\begin{array}{l}\text { Emphasizes on excellence and } \\
\text { competitiveness }\end{array}$ \\
\hline
\end{tabular}




\begin{tabular}{|l|l|l|}
\hline \multicolumn{1}{|c|}{ Topics } & \multicolumn{1}{|c|}{ 8-4-4 Curriculum (Old) } & \multicolumn{1}{c|}{ 2-6-6-3 Curriculum (New) } \\
\hline Curriculum Basis & Objective based participants & Competency based \\
\hline Mode of learning & $\begin{array}{l}\text { Teacher at the centre of learning with } \\
\text { learners being more of passive }\end{array}$ & $\begin{array}{l}\text { Learners at the center of learning and } \\
\text { teachers' duty is to facilitate learners }\end{array}$ \\
\hline Methodology & $\begin{array}{l}\text { More rigid in content, learning time } \\
\text { and strategies }\end{array}$ & $\begin{array}{l}\text { Flexible, responsive and supportive in } \\
\text { embracing diverse learning needs and } \\
\text { abilities }\end{array}$ \\
\hline $\begin{array}{l}\text { Mode of } \\
\text { assessment }\end{array}$ & $\begin{array}{l}\text { Concentrates on summative } \\
\text { assessment (KCPE, KCSE) }\end{array}$ & $\begin{array}{l}\text { Balances between formative and } \\
\text { summative assessment }\end{array}$ \\
\hline involvement & $\begin{array}{l}\text { Very little parental engagement and } \\
\text { support }\end{array}$ & $\begin{array}{l}\text { Engage parents through empowerment } \\
\text { and allow shared responsibility in all tiers } \\
\text { and levels of basic education }\end{array}$ \\
\hline Transition & $\begin{array}{l}\text { Not guaranteed especially for learners } \\
\text { with disabilities }\end{array}$ & $\begin{array}{l}\text { Transition is guaranteed for all learners } \\
\text { through different pathways, expect for } \\
\text { special cases of disabilities }\end{array}$ \\
\hline
\end{tabular}

\section{Research Methodology}

The article used desk research and qualitative methods to gather data and give interpretation of it. The researcher majorly relied upon secondary levels reviewing of literature and drawing on national and regional level educational policy documents. The literature was additionally verified with selected key informant and institutional level interviews in Kenya. The researcher used qualitative research approach in this article to unearth deep details of the education system and reforms since independence in 1963. In addition to that historical design was adopted in reviewing educational development during colonial and under the leadership of the four presidents of the republic of Kenya in post-colonial times.

\section{Trends of Education Policies and Reforms}

The education sector in Kenya has undergone several changes and challenges since independence. In order to overcome these challenges, the government has formulated and implemented various policies through the past five decades. It is worth noting that various educational commissions, committees, and task forces in most cases were formed to address the education sector problems. Since the education system was adopted from the colonial British government during independence, the education commissions and reports at first were tailored towards promoting national unity and the creation of adequate human capital. Later in the 1980s, reports in addition to national unity and sufficient human capital focused on social, economic, and cultural undertakings. The national goals and vision towards the education sector focused on a wider dimension. The 1990s' and 2000s' education policies and reports focused on education funding, quality, relevance, and general education problems, such as insufficient teachers, school infrastructure, and cultural-related issues.

It is important to note that until today, the majority of Kenyans, about 74.4 percent, live in rural areas (World Bank, 2015) with limited access to well-resourced primary and secondary schools and only between 24 and 36 percent of the students that finish primary school join secondary schools. Inequality and complex physical terrain without 
access to infrastructure and poverty are among the leading factors that limit access to education among the majority of the Kenyan rural population five decades after independence. Since 2007, the government has extended free basic education to secondary schools. In this case, the government provides funding for tuition and learning materials. The parents on the other hand are required to pay for other costs such as lunches and infrastructure development. This policy has been unable to address the inequality in education because in most cases, the cost of infrastructure development is often higher than the majority of rural poor parents can afford. As a result, schools that have already developed their infrastructure tend to do better than the majority of those that have not. Among the most critical challenges that the education sector faces still today are increased inequality, lack of access to education, high costs of basic and higher education, and quality (Somerset, 2011).

\section{Education Policies During Early Missionary, Colonial and Independence Times}

In order to understand the colonial education policies in Kenya and how their legacies have continued to impact the context of education policies today, three historical events are important: 1) early Christian missionary activities, 2) early European and in particular British interest in Kenya, and 3) education during independence.

Christian missionaries who built schools, hospitals and churches in Kenya in the 1800s started the first and dominant education for Africans. German missionaries were the first to establish schools along the Kenyan Coast in the 1840s. Access to education provided by Christian missionaries was limited to the areas that the missionaries had reached and the resources they had as missionary activities were not funded by governments. It is also important to note that the most dominant missionary communities, namely German, American, and British, settled in different parts of the country, and came from different Christian denominations, for instance Catholic, Anglican, Methodist, Lutheran, Quaker, and Presbyterian. Since missionaries came from different countries, they came with different education policies, approaches, and resources. Each provided education independent of the others (Keshavjee, 2010). By the 1920s, for example, a number of Christian missionary organizations had established schools in Kenya (Amatsimbi, 2013). Even though early British settlers had arrived in Kenya by 1846, education for Africans was not funded by the first British education department, therefore making it difficult for African children to join schools.

As a result, Christian missionaries remained the sole financiers of education for Africans. They owned all of the schools and financed public education (Mwiria, 1991). At the end of the First World War, Kenyan soldiers returning from the war abroad had been exposed to global politics. They had been recruited into the British Army, fought alongside their British counterparts, and learned English as well as about political organizations. They used their skills in war and politics to mobilize and organize the local people to form political organizations to resist British racial policies. Local political organizations such as the Kikuyu Association and Young Kavirondo Association were formed. These groups were instrumental in pressuring the colonial government to fund education and to provide equal quality education for all since it 
was collecting high taxes from the locals (Amatsimbi, 2013). In the 1920s, local political pressure and resistance pushed the colonial government to get involved in education. However, not much was achieved until Kenya's independence in 1963.

In 1884, Germany's imperial chancellor, Otto von Bismarck, convened the Berlin conference (November 1884-February 1885). The goal of the conference was to partition Africa among European powers. This would prevent conflict and possible war among the European powers over Africa. Before 1884, European powers such as the U.K., Spain, France, Portugal, Belgium, and Germany had been involved in different parts of Africa where they made trade treaties with local kingdoms and councils. Africa had been all along a great source of resources, including minerals and raw materials. However, this was culminating into a conflict among the European powers as each European nation sought to expand its territory in Africa (Okeke-Agulu, 2010). It is important to note that the 19th century was the peak of industrialization in Europe. Raw materials, most of which were drawn from Africa, were essential for the European economy and a long-term strategy to control these resources was necessary.

Prior to the Berlin Conference, two European nations were dominantly involved in East Africa (Present Kenya, Uganda, and Tanzania). The United Kingdom occupied present Kenya and Uganda, and Germany occupied Tanzania. Their early involvement was tied to commercial explorations and interests that were based on treaties with local community councils and kingdoms. These treaties were viewed as temporal and were hence exposed to uncertain change if and when a new European nation would come into the region with a more lucrative trade deal. A common understanding among the European powers was to find a international political and economic mechanism that would enable them to protect the resources in the areas in which they were involved in Africa for the benefit of their countries. In the United Kingdom, the economy was on the decline following the impact of, among other things, the United States of America's independence. Establishing protectorates in Africa as a source of free or cheap raw materials was a necessary alternative.

In the 1884/85 Berlin Conference, the U.K. acquired Kenya and Uganda as a British East Africa protectorate. From that time on, the U.K. established a formal presence in and occupation of this region. Its economic and political structure was basically one multinational company, Imperial British East Africa (IBEA), backed by a lean British Authority. The company brought together a swath of British investors with interest in agriculture, mining transport etc. The local British authority was meant to build the confidence of the British people in investing in East Africa (Gjersø, 2015). In 1888, Imperial British East Africa was granted the Royal Charter to exploit the British spheres of influence in East Africa. In 1895, the U.K. declared Kenya a British protectorate. Soon afterward, white settlers from the U.K., Australia, and South Africa began to arrive and settle in Kenya (Mwiria, 1991). It is important to note that from the start, the U.K. did not have a clear policy for developing an economic development strategy for East Africa but rather a policy to extracted resources and protected this extraction.

The inequality in education in Kenya is rooted in the fact that right from the start, the British state did not have a definitive education financing policy for all of its 47 colonies around the world, Kenya included. This approach to education prevailed until the 
1960s. As a result, the education sector was guided by flexible general principles controlled by the Secretary of the State for the colonies. Therefore,

education financing policies depended on 16 well-outlined factors such as the attitude of the colonial governor towards educating local people in the colony, the status of the director of education in the colony, the influence of Christian missionaries in the colony and in London, the conditions of the local economy, and Strength of Local African pressure groups amongst other factors (Whitehead, 2007). In 1920, Kenya was declared a British colony and Africans opposed the decision. At the time, a sizable number of British settlers had settled largely in the Kenya highlands and in major towns where infrastructure was centralized. Education soon became a key instrument of colonization. A number of measures formed early British education policies: 1) the Kenyan society was categorized into three racial categories, namely Africans, Asians (mainly Indians), and Europeans; 2) national values were organized along racial ideology that became the ruling ethic; and 3) resources allocated to the education sector were distributed. While all Kenyans were taxed, more revenue to the education sector was allocated to European followed by Asian (Indian) schools even though these were the minority. European schools used a different curriculum, which was defined as superior to the one used in African schools (Mwiria, 1991). The colonial education system was based on a model of discrimination, which saw the establishment of separate educational systems for Africans, Asians and Europeans, a factor that perpetuated inequalities in accessing education more so for the African population" (Keriga \& Bujra, 2009: 2; Mulwa et al., 2011).

By 1925, there was no single public high school for Africans in the country. In response, the Kiambu Local Native Council decided to build the first high school in Githunguri for the community. Mobilized by the Kikuyu Association, they sought permission from the colonial government, which at the time controlled licensing. Other Local Native Councils countrywide, namely, Nyeri, Murang'a, North Nyanza (Abaluhyia), Central Nyanza (Luo), and South Nyanza (Kisii), each voted to raise $\mathcal{E}_{10}, 00$ for the construction of the schools. Even though local communities had their own resources to build schools, the colonial government refused to grant the permit. In protest and civil disobedience, the Local Native Councils began to raise funds for the schools and opposed the government authority in their areas. The resistance took 5 years until 1930 when the colonial government granted the permits, having realized the growing agitation (Wamagatta, 2008). Access to primary education was also restricted for Africans. Colonial policies limited the number of primary schools for Africans on the basis of cost control.

On the other hand, European and Asian children were entitled to open access to seven years of primary and four years of secondary education. In 1947 for example, European children received $60 \%$ of government funding compared to $0.4 \%$ allocated to African children. In order to curb the inequality, missionary schools provided $41 \%$ of the funding to African children through missionary schools while African communities through community self-help organizations provided $54 \%$ of the funding for African children. However, inequalities prevailed. By the $1950 \mathrm{~s}$, about a decade to independence, $98 \%$ of Europeans were attending secondary school. In 1953, 90\% of the students enrolled in schools public and private combined were Africans. However, 
only $10.7 \%$ of the total expenditure, recurrent and non-recurrent, was allocated to the education sector. Furthermore, only $49 \%$ of this was allocated to the education of Africans even though Africans constituted the majority of the population in need (Somerset, 2011).

The independence was the turning moment of education provision, especially for the black Kenyan population. All Kenyans were now able to attend schools without racial or any restrictions as existed during colonial masters. This study has divided education reforms and development into four presidential eras as discussed below.

\section{Education Policies and Reforms Under Different Presidents (1963-2020)}

\section{President Kenyatta's Government (1964-1978)}

The first president of Kenya and founding father was His Excellence the Later Mzee Jomo Kenyatta and he was the president from 1963 to 1978 . He had just taken power from the British Imperial colonizers and it was during his leadership that many sectoral policies were put into place, including education policies. Kenya established an education commission in 1964 immediately after its independence in 1963. This commission was to meet for two goals. One was to develop reliable and skilled "manpower" to propel the economy, and second, to help in eradicating poverty in the country (Eshiwani 1993). A number of education policies and reforms to kick-start the education sector after the colonial masters had left were formed during this period. His Excellence the late President Mzee Jomo Kenyatta was at the forefront to fight three main "enemies" of development: illiteracy, poverty, and disease. This essence was meant to improve human power through the provision of education and the improvement of poor citizens' welfare during independence. The elimination or reduction of these three "enemies" of development was crucial for a young nation that needed more skilled and enough manpower in order to improve its economy. In the first decades after independence, the approach to education policies did not change much. A number of reforms and changes in education policies relied deeply on the recommendations of education commission reports (Opondo, 2000).

The first education reforms were based on the 1964 Ominde Report, which basically provided recommendations on reforming the colonial education system. It was meant to provide a policy framework for restructuring the education system in Kenya, from a colonial-oriented system to one that would foster national unity and development during the post-independence era. The commission had 160 policy recommendations on different aspects of the education system. As a result of the report, the government brought to an end racial schools and a racial education system. It also granted bursaries for African students to join former European and Asian schools (Soft Kenya, 2020). By 1966, the number of community owned and financed schools (Harambee Schools) had increased to 226 compared to 199 government funded schools. As a result, the government in 1967 began to assist the Harambee schools by paying qualified teachers. Under the First president of Kenya and the founding father, His Excellence the later Mzee Jomo Kenyatta and who was the president from the year 1963-1978. He had just taken power from British Imperial colonizers and it was during his leadership time that many sectoral policies were put into place, including education policies. 


\section{President Moi's Government (1978 - 2002)}

Since independence, investment in education was based on the belief that education would trigger economic growth and development. This idea prevailed in the second era of Kenya's presidential regimes (1978-2002). After 14 years of Kenyatta's postindependence regime (1963-1978), Kenya was still facing pressure to meet the social demand for education since the education infrastructure was still inadequate to meet the growing demand for education at the time (Muricho \& Chang'ach, 2013). The provision of subsidized education in Kenya has been a major "tool" for political party campaigns to gain fame and to be voted in. The previous governments' manifestos placed the provision of free or subsidized education as a top priority. The leadership of the former second President of Kenya, the late President Daniel Torotich Arap Moi, failed to expand education in a sustainable way even though key policy reforms were formulated and implemented during this period. The reports of Mackay (1981), Kamuge (1988), and Koech (1999) were crucial during this era and led to the recommendation of the 8-4-4 education system, the cost-sharing of school costs, and the introduction of research policy in that order. Another notable reform was the introduction of the Kenya National Examination Council (KNEC) in 1980 to manage and conduct examinations for primary, secondary and some tertiary institutions. This was in an attempt to regulate examination management and to raise education standards and trust in the system.

Foreign aid played a significant role in financing Kenyan education policies. According to Barkan (1994), president Moi' government represented the voice of the marginalized communities located in the comparatively underdeveloped areas inhabited by the poor and underprivileged people. Barkan (1994) explained that President Moi was committed to ensuring a more equitable distribution of resources for education and in 1978 he announced free primary education in as a measure to enable more participation by poor children. Later President Moi introduced free milk program to help feed poor children attending all public schools in Kenya. Foreign aid in part reduced the direct cost of education that had in the earlier years become a burden to parents, especially since parents were required to pay infrastructure levies that kept increasing. As a result, enrolment rates fell during the early years of this period because many poor parents could not afford the levies. Furthermore, structural adjustment programs forced the government to reduce spending on education and to re-introduce use charges.

The government also halted the expansion of public schools in areas that did not have access to education. In this case, areas formerly marginalized remained largely without access to education. Communities, however, continued to build more community (Harambee) schools, and the community schools continued to absorb more students than government schools even though they had limited infrastructures. From the late 1980 s to the early 1990 s, Kenya was transitioning to a multi-party democracy. Politicians made access to education a political campaign agenda, forcing a shift in government education policy, and the government began to embrace and support community schools (Colclough \& Webb, 2012). 


\section{President Kibaki's Government (2002 - 2013)}

Just like his predecessors, the third president of Kenya, H.E. President Mwai Kibaki, made education a centerpiece of his electoral manifesto and without finding the best ways to sustain free education, his party quickly implemented a third Free Primary Education initiative in 2003. The introduction and implementation of FPE in 2003 was tricky because of the fact that sound analysis and assessment were superseded by political expediency, which led to inadequate preparation, consultation, planning, budgeting, and a smooth implementation of the program (Sifuna, 2007). Even with the above mistake, the expansion of access to basic education was the cornerstone of this presidential era and can be explained by the following reasons. First, the foreign aid for education that had been frozen in the late 1980s to early 1990s was reintroduced and increased. Second, Kenya had domesticated the Millennium development goals and had additional support as a result of that. Third, Kenya's vision 2030 was strategically anchored in improving access and quality of education as an instrument of sociopolitical transformation. Fifth, Kenya's 2010 constitution made access to education a constitutional right and obligated the government to re-distribute and devolve resources to the education sector on the basis of constitutional imperative measures.

Kenya's long-term development plan, Vision 2030, is an aspirational document with the intention to transform it into an upper-middle-income country by 2030 (GoK, 2017). The framework for the document is based on three pillars: economic, social and political. According to Vision 2030, the aim of the economic pillar is to improve the prosperity of all Kenyans, the social pillar seeks to attain a just and cohesive society with social equity in a clean and secure environment while the political pillar endeavors to realize a democratic political system founded on issue-based politics that respects the rule of law, and protects the rights and freedoms of every individual in Kenyan society' (GoK, 2017).

In the years 2003 and 2007, the NARC government reversed the cost-sharing policy that included user charges and infrastructure levies. The policy was unpopular and had been a key component of the NARC campaign agenda in 2002. Basic education was meant to be free of indirect and direct charges. This resulted in the increase in primary school enrolment (Somerset, 2011). Despite all these changes, access to secondary education remained low. In 2009 for instance, secondary school enrolment rate was at about 50 percent while the primary to secondary school transition rate remained low at 55 percent (Odhiambo, 2016). Free Day Secondary Education was introduced in 2008 under the leadership of President Mwai Kibaki and Prime Minister Raila Amolo Odinga in their coalition government. This secondary education policy was introduced to help the students from poor household access secondary education, which was low in terms of enrolments. Also, during this period, the introduction of Kenya's blueprint (Vision 2030) was introduced in 2008 and the New Constitution of 2010, both of which supported education initiatives and emphasized equitable resources. 


\section{President Uburu's Government (2013 - to date)}

The current government under the leadership of H.E. President Uhuru Kenyatta has done much in the last 5 years on education policies and reforms. The notable education policies include provision of a Laptop/Tablet project for class one pupils in lower primary schools countrywide, and the Basic Education Act (2013) which failed. This is an Act of parliament to give effect to Article 53 of The Constitution and other enabling not the provisions to promote and regulate free and compulsory basic education but also to provide room for the establishment of the National Education Board and the Education Standards and Quality Assurance Commission.

President Uhuru's Jubilee Party in 2013 promised to give laptops to all pupils joining primary school during their party national campaigns. The Jubilee party won election and the laptop promise was among its first to fulfill. The aim of the project was to promote digital literacy and prepare the young learners to thrive in ICT based economy (Mugendi, 2019). The laptop project promise was fulfilled in 2016, but with tablets instead of laptops. The project was silently retired six years after the announcing and three years after the implementation. The truth about the impossibility of sustaining the project started to be clear and this explains why the most politically motivated promises are done without regard to many basic principles of public policy formulation. In 2019, the government of Kenya sunk Sh8.4 billion into this controversial laptop project that has so far gobbled up in excess of Sh50 billion. The Jubilee government allocated the laptop project Sh17.6 billion, Sh13.4 billion and Sh13.4 billion in the years 2015, 2016 and 2017 respectively. Later in 2018, the government allocated Sh6.3 billion and as one can see, the budget allocated to this project kept on varying not progressive in nature (Odhiambo, 2019). It is good to note that during the project period, the Kenya Institute of Curriculum Development (KICD) report exposed that only 39 per cent of the teachers use the gadgets to teach (Odhiambo, 2019).

According to Mugendi (2019), this project was bound to fail because of the following reasons: Firstly, it would be extremely costly to run the project; secondly, the government lacked skilled personnel to run the program which was a major hindrance; thirdly, the priorities of the government were wrong from the beginning since schools lack teachers, classrooms, connection to the grid, and in some places, there are no schools; fourth, lack of requisite infrastructure - only $10 \%$ of schools were connected to the grid while 50\% were far away from the national grid; and lastly, lack of support mechanism when technology failed - this left both teachers and learners stranded. The best thing the government could have done to sustain this project was to build computer labs in all primary and secondary schools in Kenya.

\section{Challenges, Conclusion and Policy Recommendation}

\section{Challenges of Education Reforms in Kenya}

The Kenyan government has been in the forefront to bring changes and reviewing education policies through various education commissions. These education commissions have shaped the education system since independence to the level it is at 
the moment. Nevertheless, the following are the key challenges that have gone against the spirit and objectives of education reforms (Muricho \& Chang'ach, 2013):

1. There has been resistance to education change or reforms from some stakeholders such as KNUT, parents, Teachers and International organizations such as UNICEF.

2. Political interference - major education policies were suggested by major political parties that only needed votes.

3. Lack of reliable and sustainable funding to implement education reforms such as free primary and secondary education.

4. Lack of enough time to assess the policy, poor planning and non-implementation of reforms.

5. Almost $3 / 4$ of Kenyan population are youth - explaining the greater number of youth being unemployed.

6. Physical facilities are insufficient leading to overcrowding in learning institution henceforth the quality of education is low and not to standards.

7. Population growth is also a big challenge - more pupils and students enroll to schools each year big numbers and this has overwhelmed the government in providing free education to all.

8. Many reforms failed to be implemented for example laptop project, free primary and secondary education.

\section{Conclusions}

The Republic of Kenya has a principled idea and plan of education devolution in the 21 st century, which is allied to democracy, openness and transparency in all the public institutions found in the country. Transfer of decision making to secondary schools, when efficiently applied, can result to higher student performance, more well-organized use of resources, increased skills and support for the school. To decentralize education is not an easy thing, many countries have tried it but failed and Kenya has not been spared. Kenya should strive to overcome any limitations towards effective decentralization of education so that it may enjoy benefits that come with it.

The government had to introduce free primary education in 2003 in an effort to increase enrollments, reduce dropout rates, and increase completion and transition rates. The third president of Kenya, H.E. President Mwai Kibaki, was the person that led this second free primary education in Kenya and this time around it covered all primary expenses. The free primary education programme has brought significant benefits to the country despite the challenges it has brought. Some of the poor and marginalized communities have been able to take their children to school, and if it were not for the free primary education program, the children could not have received basic education. The government's efforts in promoting and making education accessible can be seen in its ever-increasing financial allocation to the education sector. The fourth president if Kenya, H.E. President Uhuru Kenyatta introduced payment KCPE and KCSE examinations fee for standard eight and form four students respectively. 


\section{Policy Recommendation}

The policy planners would understand and appreciate education policies within which they are supposed to operate in providing effective leadership and management practices in the development of education. In order for education to foster development, this article recommends the need to separate educational policies from national politics, clear stipulation of educational policies and their role in national development and a sound implementation of educational reforms. The following are specific recommendations:

1. There is need to come up with a legal document probably to replace or improve the Education Act of 1968, would be very necessary since that will not be legally challenged, in comparison with other policy documents, which can easily be legally challenged. Therefore, a comprehensive legal document should be aligned with democratic governance, devolution of decision making and services in education sector.

2. Students should be practically involved in decision making through democratically elected students' councils. The introduction of the students' council might help Kenyan democracy in the long run by teaching the students a few things about civic duty and peaceful competition for elected office.

3. The role and capacity of the stakeholders should be well defined and developed, respectively. All the stakeholders need to be trained on their role in a decentralized system. Teachers should acquire the necessary skills and attitudes through induction and re-training and, where possible, some skills such as financial management should be emphasized on during training in colleges and universities.

4. Useful strides toward stimulating access and transition in primary and secondary schools

a) The governments through the Ministry of Education, Science and Technology needs to recruit additional teachers to support the 100 percent transition policy of the government a longer period of time.

b) There is need to build computer labs in primary and secondary schools in Kenya so as to embrace use of technology and be at per with rest of the World.

c) There is need to expand educational infrastructure in that way allowing higher student enrollment and transition rates.

d) Developing and adopting a unit cost of education and training for each learner and trainee with disability that will inform its allocation.

e) There is need to increased capitation to Free Primary Education and Free Day Secondary Education.

f) The government to continue providing examination fees for all students doing KCPE and KCSE examinations each year. 


\section{References}

Abuya, B. M. O, \& Musyoka, P. (2013). Why do pupils dropout when education is 'free'? Explaining school dropout among the urban poor in Nairobi. Compare: A Journal of Comparative and International Education, 43(6), 740-762.

Amatsimbi, H. S. (2013). Christian missions, government and local councils partnership in educational development: The case of western Kenya, 1911-1938. International Journal of Education and Research, 1(9), 1-14

Amutabi, M. N. (2003). Political interference in the running of education in postindependence Kenya: A critical retrospection. International Journal of Educational Development, 23(2), 127-144.

Barkan, J. D. (1994). Divergence and convergence in Kenya and Tanzania: pressures for reform. Beyond capitalism versus socialism in Kenya and Tanzania, 1-49.

Bwonda, E. N. (2013). Essays on benefit incidence and efficiency of public spending on education in Kenya. (Unpublished dissertation), University of Nairobi, Nairobi.

Colclough, C., \& Webb, A. (2012). A triumph of hope over reason? aid accords and education policy in Kenya. Comparative Education, 48(2), 263-280.

Digolo, O.O. (2006). The challenges of education in Kenya in the 21 st Century. Journal of the School of Education. The Educator, 1(1), 2-3.

Eshiwani, G. S. (1993). Education in Kenya since Independence. Nairobi: East African Educational Publishers.

Gjersø, J. F. (2015). The scramble for east Africa: British motives reconsidered, 1884-95. The Journal of Imperial and Commonwealth History, 43(5), 831-86.

Government of Kenya(GOK) (2017). Vision 2030. Retrieved from www.fao.org/fileadmin/ user_upload/drought/docs/Vision\%202030-\%20Popular\%20Version.pdf

Imana, D. K. (2017). Public Expenditure on Education in Kenya: Analysis of Recent Trends, Education Provision, and Income Distribution (Doctoral dissertation, National Institute of Development Administration).

Imana, D. K. (2016). The Socio-Political Context of Public Spending in Kenya: A Case of Education Inequality in Turkana County. International Journal of Educational Research and Information Science, 3(2), 5-12.

Keshavjee, R. (2010). The elusive access to education for Muslim women in Kenya from the late nineteenth century to the "Winds of Change" in Africa (1890s to 1960s). Paedagogica Historica,46(1-2), 99-115.

Keriga, L., \& Bujra, A. (2009). An evaluation and profile of education in Kenya. Development Policy Management Forum.

Kwach, J. (2019: Top 5 Challenges of the 2-6-6-3 education system in Kenya. Retrieved from www.Tuko.co.ke online newspaper, on 21.04.2020.

Lewin, K. M. (2009). Access to education in sub-Saharan Africa: Patterns, problems and possibilities. Comparative Education, 45(2), 151-174.

Lindzon, J. (2020). School Closures are starting, and they'll have Far-Reaching Economic Impacts. Retrieved on 2020-04-03 from https://www.fastcompany.com/90476445/ school-closures-are-starting-and-theyll-have-far-reaching-economic-impacts

Mugendi, J. (2019). Kenya's primary school laptops project failed. Retrieved on 15.04 .2020 from https://www.iafrikan.com/2019/08/15/kenyas-failed-primary-school-laptops-project/

Mulwa, D. M., Kimiti, R. P., Kituka, T. M., \& Muema, E. N. (2011). Decentralization of Education: The Experience of Kenyan Secondary Schools. 
Muricho, W. P., \& Changach, J. K. (2013). Education reforms in Kenya for innovation. International Journal of Humanities and Social Science, 3(9), 123-145.

Mutuku, S., Ngui, D., \& Korir, J. (2019). Government Expenditure and Quality of Education: A Case of Public Primary Schools in Kenya. Modern Economy, 10(12), 2405.

Mwiria, K. (2002). Vocationalization of Secondary Education: Kenya Case Study Prepared for Regional Vocational Skills Development Review. Human Development, Africa Region, World Bank.

Mwiria, K. (1991). Education for subordination: African education in colonial Kenya. History of Education, 20(3), 261-273.

Kithinji, M. M. (2016). Education System and University Curriculum in Kenya: Contentions, Dysfunctionality, and Reforms since Independence. In Kenya After 50 (pp. 21-40). Palgrave Macmillan, New York.

Ngware, M. (2019). Where Kenya is Spending Money on Education and What's Missing. Retrieved on 2020-04-03 from https://www.google.com/amp/s/theconversation.com/ amp/where-kenya-is-spending-money-on-education-and-what's-missing-119393

Njagi, M. S. (2018). Factors influencing Provision of Quality Education in Newly Established Secondary Schools in Mathira Constituency, Kenya (Master Thesis. Karatina University).

Odhiambo, G. (2016). Higher education in Kenya: an assessment of current responses to the imperative of widening access. Joumal of Higher Education Policy and Management, 38(2), 196-21.

Odhiambo, M. (2019). State to spend Sh8.4bn more on school tablets. Retrieved on 15.04 .2020 from https://www.the-star.co.ke/news/2019-02-16-state-to-spend-sh84bn-more-on-school-tablets/

Ojiambo, P. O. (2009).Quality of education and its role in national development: A case study of Kenya's educational reforms. Kenya Studies Review, 1(1), 133-149.

Okeke-Agulu, C. (2010). Who Knows Tomorrow. Art Journal, 69(4), 49-65.

Opondo, A. (2000). Cultural Policies in Kenya. Arts Education Policy Review, 101(5), 18-24.

Psacharopoulos, G. (1988). Education and development a review. The World Bank Research Observer, 3(1), 99-116.

Republic of Kenya (2017). Basic Education Curriculum Framework. Nairobi: Kenya Institute of Curriculum Development.

Reynolds, D., Sammons, P., De Fraine, B., Van Damme, J., Townsend, T., Teddlie, C., \& Stringfield, S. (2014). Educational effectiveness research (EER): A state-of-the-art review. School Effectiveness and School Improvement, 25(2), 197-230.

Romer, P. M. (1990). Endogenous technological change. Journal of Political Economy, 98(5, Part 2), S71-S102.

Rosen, H. S. (1999). Public Finance. New York: McGraw-Hill.

Sheffield, J. R. (1973). Education in Kenya: An historical study. New York: Teachers College Press.

Sifuna, D. N. (2007). The challenge of increasing access and improving quality: An analysis of universal primary education interventions in Kenya and Tanzania since the 1970s. International Review of Education, 53(5-6), 687-699.

Soft Kenya, (2020). Kenya Education. Retrieved from https://softkenya.com/education/ educationcommissions-in-kenya.

Somerset, A. (2011). Access, cost and quality: tensions in the development of primary education in Kenya. Journal of Education Policy, 26(4), 483-497.

UNESCO(a), 2020: COVID-19 Educational Disruption and Responses. Retrieved on 2020-04-02 from http://en.unesco.org/covid19/educationresponse

UNESCO(b), 2020. Adverse Consequences of School Closures. Retrieved on 2020-04-03 from https://en.unesco.org/covid19/educationresponses/consequences 
30 The politics of education reforms in Kenya

UNESCO(c). (2018). UIS Stats - Education. http://data.uis.unesco.org/

UNESCO(d). (2017). A guide for ensuring inclusion and equity in education. Retrieved from http://unesdoc.unesco.org/images/0024/002482/248254e.pdf

UNESCO (e), Institute for Statistics. (2006). EFA Global Report 2006. Literacy for Life: Retrieved from http://en.unesco.org/gem-report/sites/gemreport/files/149776E.pdf.

Wamagatta, E. (2008). African quest and struggle for high schools in colonial Kenya. The Case of the Abortive Kiambu Local Native Council Central High School at Githunguri, 1926-34. Journal of Asian and African Studies, 43(3): 345-362.

Wanjala, G., \& Malechwanzi, J. M. (2016). Improving the quality of technical education through international standardization: The case of coast institute of technology, Kenya. In Fast forwarding Higher Education Institutions for Global Challenges (pp. 185-203). Springer, Singapore.

Wanjohi, A.M. (2017). New Education System in Kenya: An Excerpt from Basic Education Curriculum Framework. Retrieved from http://schoolsnetkenya.com/downloads/neweducation-system-in-kenya-an-excerpt-from-basic-education-curriculum-framework.pdf

Whitehead, C. (2007). The Concept of British Education Policy in the Colonies 1850-1960. Journal of Educational Administration and History, 39(2), 161-173.

World Bank (WB). (2015). Kenya rural population (\% of total population). World Urbanization prospects Retrieved from

http://data.worldbank.org/indicator/SP.RUR.TOTL.ZS?locations=KE 